\author{
Marta Rogowska \\ mgr inż. \\ Instytut Kolejnictwa, Warszawa \\ mrogowska@ikolej.pl
}

DOI: 10.35117/A_ENG_17_07_03

\title{
Testing railway capacity using modern microsimulation programs
}

\begin{abstract}
In a time of dynamic changes in the railway market and nascent need of adjustment the infrastructure to increasing traffic flow and modern rolling stock, the issue of capacity is becoming more and more essential. In this publication the modern attempt at testing capacity - utilization of microsimulation program using as an example a section of the railway with diverse equipment is presented.
\end{abstract}

Keywords: Microsimulation; RailSys; Railway capacity

\section{Introduction}

Increasing the capacity is an important requirement for tenders announced by PKP Polskie Linie Kolejowe S.A. for the modernization of railway lines because in order for the railway to become competitive with other modes of transport it must offer the passenger an attractive offer of long-distance connections as well as within urban agglomerations.

Railway infrastructure, especially in the case of railway hubs, is constantly being designed on the basis of static capacity calculations [8]. This often leads to the fact that the constructed infrastructure does not correspond to the demand for actual traffic load in a regular timetable. Hence the wider use of simulation programs. They allow for the implementation of load adjustments in the anticipated operational plan on the model of the infrastructure being designed, identification of bottlenecks, proposal and checking options for their removal.

\section{Characteristics of parameters affecting the capacity of the railway line}

The definition of the capacity of a railway line says that it is the ability to perform on it train journeys within a certain time [18]. It is expressed in the largest number of trains or pairs of trains that can cross a given distance (part, route) of a railway line at a given time, usually, it is a day or morning and an afternoon rush hours.

The throughput capacity depends on:

- railway parameters, such as maximum permitted speed or number and nature of speed limits;

- number of tracks;

- dividing lines into trails;

- type of traffic control devices installed on the network;

- technical characteristics of trains passing through a given network element,

- i.e. type of trains, technical speed, weight and length of trainsets, locomotive traction characteristics, required braking distances;

- difficulties on the railway road, such as closures and repairs.

Too low speed on the Polish rail network is one of the problems most frequently recognized by carriers [33]. The most common reason for speed restrictions is the poor condition of a railway or engineering facility. Too low speed not only extends the driving time but also causes blocking of routes, which significantly affects the reduction of the line's capacity. 
Another parameter affecting the capacity of the line is the number of tracks, on two-way sections, it is usually possible to observe up to four times more bandwidth than on singletrack routes [27]. However, the second track does not always solve the problem of too low capacity, because the bottlenecks are stations where crossings and passing trains take place.

What is more important is the distance between successive stations, especially on singletrack lines due to the aforementioned possibility of overtaking or passing only at stations. The shorter these intervals, the shorter the travel time of the train.

The type of rail traffic control devices has a significant impact on the capacity of the line. The main task of traffic control devices is to ensure a safe distance between trains. This is accomplished by block spacing. There may be only one train on each of the spaces. Their length is very important because regardless of the position of the train on the stretch, the entire section of the line is considered to be occupied. In the book "Fundamentals of railway traffic control. Functions, requirements, and the outline of the technique "Mirosława Dąbrowy - Bajon [6] compared succession times, bandwidth and speed at 3 ETCS levels. Some assumptions have been made:

- length of block spacing on a straight track for level 1 and 2 of 1500 meters,

- the response time of the RBC control center for level 2 and 3 or the signaling system for level 1, without taking into account the adjustment of the crossover $-5 \mathrm{~s}$,

- train length up to $400 \mathrm{~m}$,

- guaranteed delay value in curbing $-0,6 \mathrm{~m} / \mathrm{s}^{2}$,

- brake system response time $-6 \mathrm{~s}$,

- driver's reaction time $-5 \mathrm{~s}$,

- capacity margin of the line $-10 \%$.

What was shown with these assumptions is shown in the table below.

Tab. 1. Comparison of 3 ETCS levels due to capacity

\begin{tabular}{|c|c|c|c|}
\hline ETCS level & $\begin{array}{c}\text { train succession } \\
\text { time tn }[\mathbf{m i n}]\end{array}$ & $\begin{array}{c}\text { capacity } \mathbf{N}_{\max } \\
{[\mathbf{p o c} / \mathbf{h}]}\end{array}$ & speed $\mathbf{v}_{\max }[\mathbf{k m} / \mathbf{h}]$ \\
\hline 1 & 3 & 20 & 160 \\
\hline 2 & 2,5 & 24 & 300 \\
\hline 3 & 2 & 30 & 500 \\
\hline
\end{tabular}

Source: own elaboration based on data available in „Podstawy Sterowania Ruchem Kolejowym. Funkcje, wymagania, zarys techniki"

The technical characteristics of trains crossing the line are not insignificant. Mixed traffic, i.e. a situation when trains with different parameters and different categories move along the line adversely affect the capacity of the line. This is mainly due to the need to overtake slower trains by the faster ones. What becomes problematic in the situations is described above. Important train parameters, due to the length of the route occupied, the maximum speed of the rolling stock, its length, acceleration and braking characteristics are.

In addition, any difficulties such as closures, particularly within a station, significantly limit the possibility of cross-train maneuvers and overtaking. What's more, for example in the case of closing side tracks, carriers after finishing the train run are forced to leave trains on the main tracks. 


\section{Principle of microsimulation programs operation}

The most popular programs used to perform microsymulation are RailSys of the German company RMCon and the Swiss OpenTrack.

Thanks to them, the user can:

- specify infrastructure requirements for the railway network,

- analyze the capacity of the line and station,

- introduce and analyze rolling stock,

- calculate the travel time,

- construct a timetable,

- design various types of signaling,

- analyze the effects of defects in the systems introduced, perform simulation.

The general principle of operation of microsimulation programs used in the design of a railway line is symbolically presented in the following graphics.

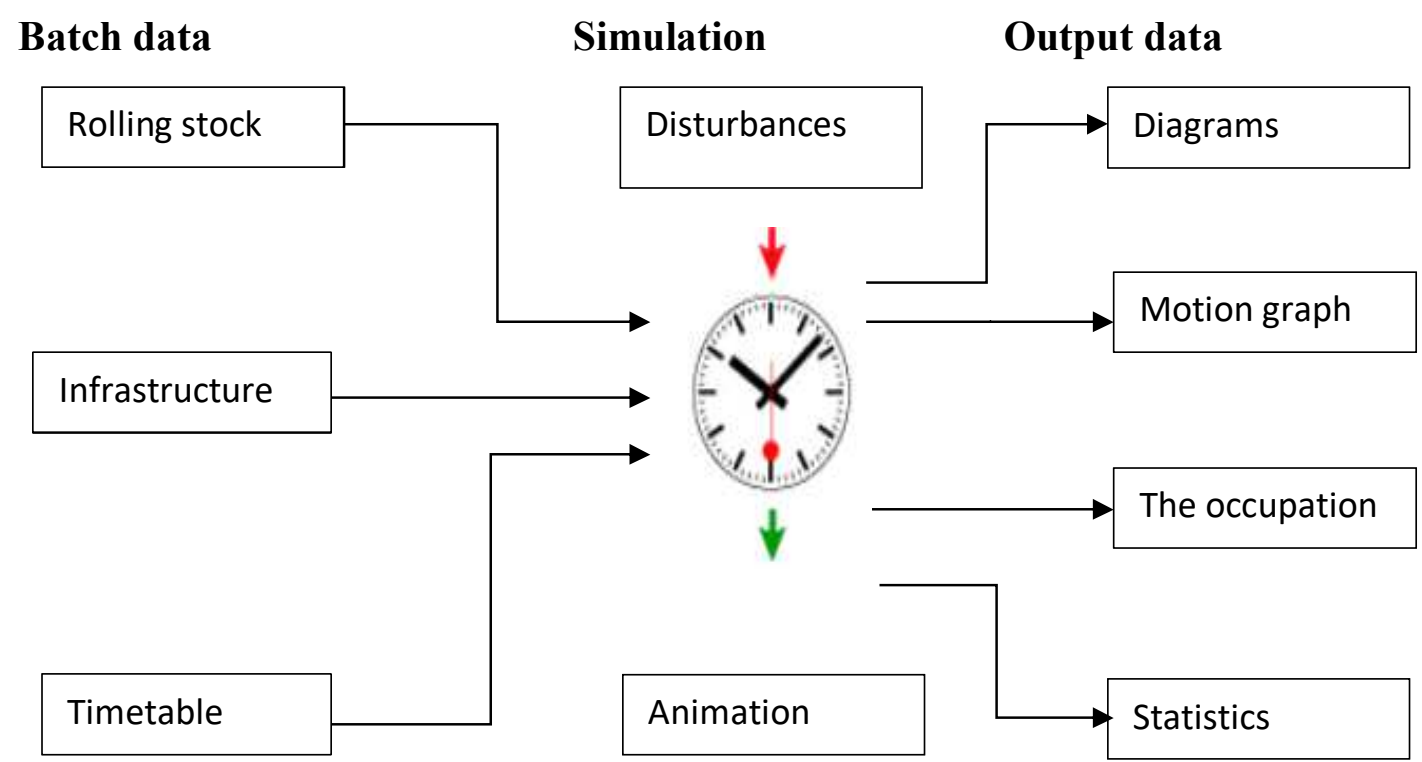

1. General scheme of operation of microsimulation programs Source: own study based on data provided by RMCon and Opentrack

The infrastructure data entered are, among others, the track system, signaling and all other relevant infrastructure elements (such as line speed, fixed speed limits, guard roads, stop indicators on platforms, block intervals, blockade interlock, etc.).

When the infrastructure is ready, it is possible to start the timetable, but before entering it, enter the data on the rolling stock, i.e. maximum speed, length, weight, number of axles, type of drive, type of rolling stock (locomotive or traction unit), additional the number of seats and standing places can be determined. 


\begin{tabular}{|c|c|c|c|c|}
\hline Base data & Acc. diagram & Dec. diagram & Rolling resistances & Comments \\
\hline \multicolumn{5}{|c|}{ Traction unit type } \\
\hline \multicolumn{5}{|c|}{ Name: EN57 } \\
\hline \multicolumn{5}{|l|}{ Data } \\
\hline \multicolumn{2}{|c|}{$V \max [\mathrm{km} / \mathrm{h}]:$} & 110 & & \\
\hline \multicolumn{2}{|c|}{ Length $[\mathrm{m}]$ : } & 64.970 & & \\
\hline \multicolumn{2}{|l|}{ Mass $[\mathrm{t}]$ : } & 126.500 & & \\
\hline \multicolumn{2}{|c|}{ Adhesion mass $[\mathrm{t}]$ : } & 126.500 & & \\
\hline \multicolumn{2}{|c|}{ Number of axdes: } & 12 & & \\
\hline \multicolumn{2}{|c|}{ Traction type: } & electric & & \\
\hline \multicolumn{2}{|l|}{ Type: } & Traction unit - & & \\
\hline \multicolumn{2}{|c|}{ Number of seats: } & 0 & & \\
\hline \multicolumn{2}{|c|}{ Amount of standing room: } & 0 & & \\
\hline
\end{tabular}

2. Sample data on rolling stock entered into RailSys Source: RailSys

In addition to the basic data, more accurate regarding traction characteristics should be introduced. For each speed an acceleration force is input and on this basis, the program generates a graph.

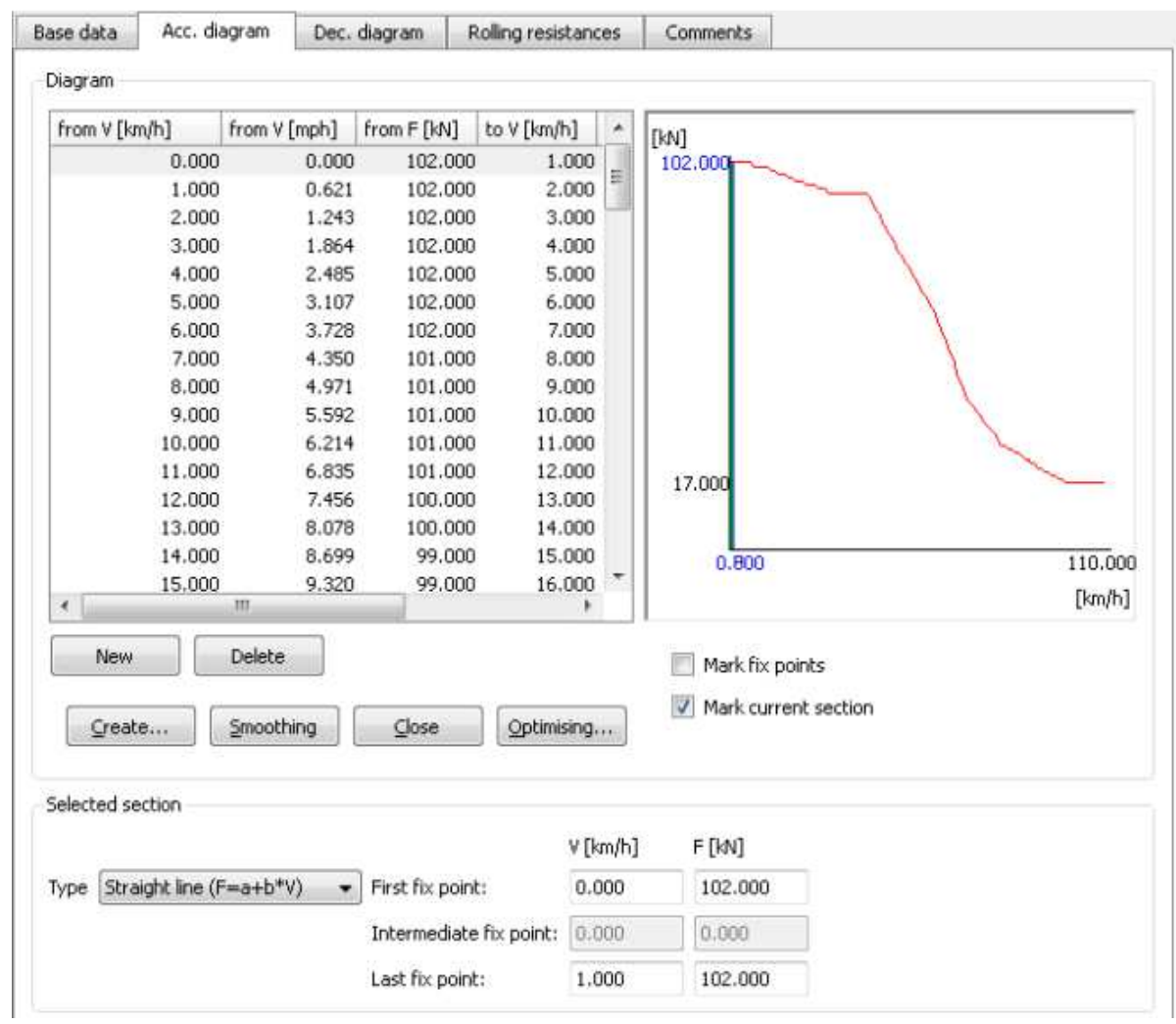

3. An example graph of the relationship of the force accelerating from the rolling stock generated in the RailSys program

Source: RailSys 
The next step is to determine the course of individual trains. After selecting the rolling stock and route, the timetable is entered, i.e. the time of arrival and departure from individual stations and stop time on them as shown in the figure below:

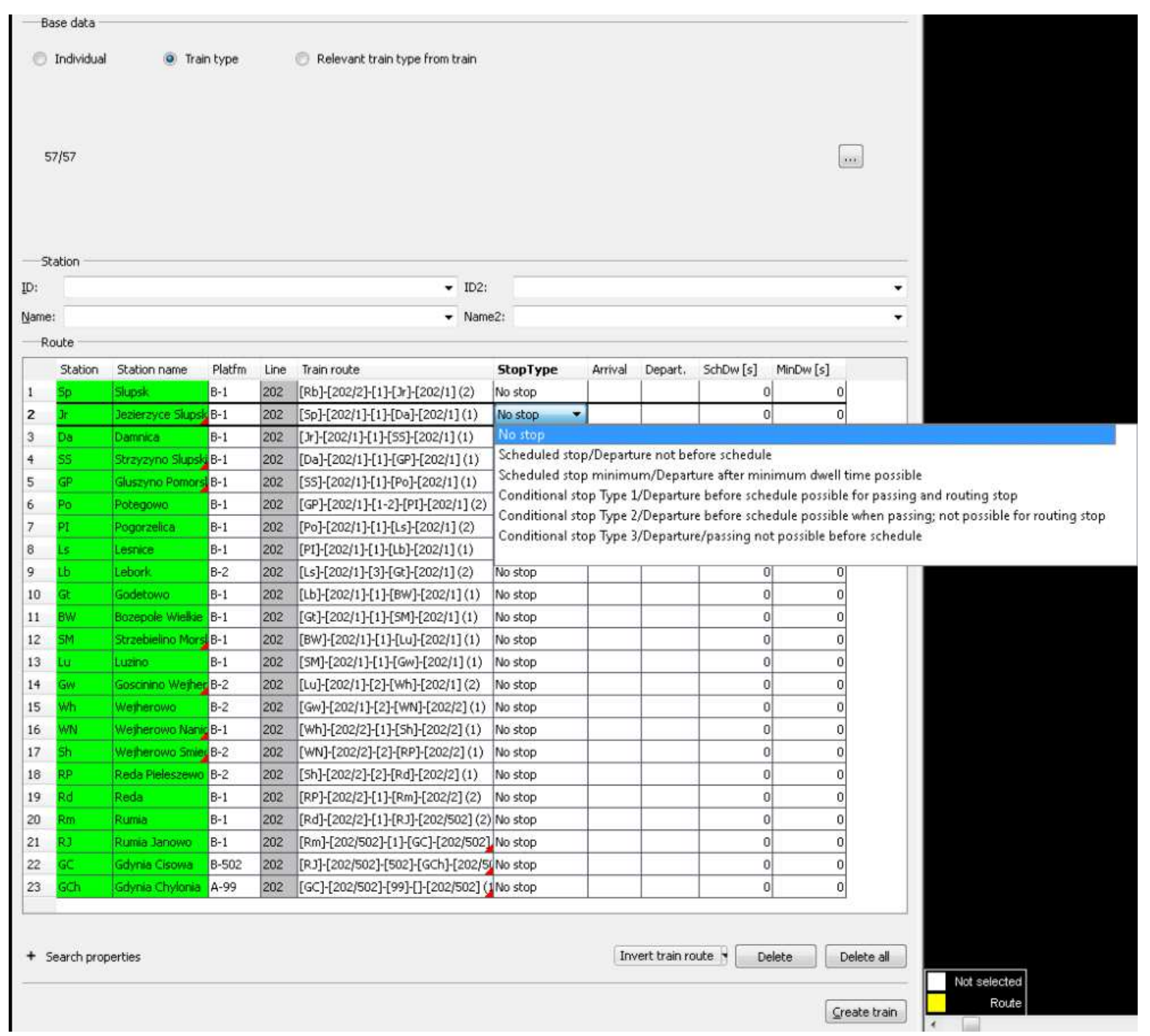

4. Example of setting the train schedule for the train in the RailSys program, taking into account the planned stops, times of arrivals and departures

\section{Source: RailSys}

The program automatically generates a traffic graph. On this basis, it detects conflicts resulting from the passage of trains taking into account the routes, block intervals or passing trains at stations. When changing the route, the program instantly recalculates travel times and generates new ones, taking into account the data on the rolling stock and infrastructure, which is why the more accurate the user input is, the more accurate and real-time the timetable will be and it will be easier to locate the so-called bottlenecks and collision venues, and thus proposing changes to improve traffic on the line or stretch.

When the timetable is entered, you can go on to simulate the passage of trains. 


\section{Parameters of the tested line segment}

In the course of the analyzes, the capacity research covered a section of a railway line more than 100 kilometers long, fully electrified, with a national significance. Only on about $10 \%$ of its length is a two-track line, only one track runs on the remaining one. There are different train speeds on the section in question. Differences are also found in the equipment of lines in railway traffic control devices - track and station. Temporary speed limits have been introduced in individual sections. There are 15 stations and 6 passenger stops on the section under development. Only passenger traffic is taken into account. The RailSys program was used for the simulation in version 8.9.92.

Four variants were compared, differing in the elements of infrastructure, train control systems, and permitted speeds, for each of the variants a new track system was introduced, a new timetable was constructed, and a suitable rolling stock adapted. For more reliable results, each of the variants was guided by the same schedule for creating timetables. Trains were divided into 5 groups, differing in routes and stops where they stop, sometimes stationary stations systematized also naming, that is numbers given to them in the timetable, as well as a specific rolling stock assigned to each group.

The trains were introduced while maintaining the rules set out above. The day was divided into hourly intervals. The most sensitive hours are the morning rush hours between 6:00 and 9:00 and the afternoon hours between 15:00 and 18:00. Trains were introduced from approximately 5:00 to 23:00, sometimes midnight.

The main rule in the generation of runs was right-hand traffic, the principle of the smallest crossings is also important, it means running trains that do not stop at the station, if possible, as the simplest route excluding crossings, still maintaining right-hand traffic.

In variant 1 , the speed of $140 \mathrm{~km} / \mathrm{h}$ has been introduced along the entire length, however, the maximum speed cannot be reached anywhere (see Table 2).

In option 2, apart from increasing the speed to $160 \mathrm{~km} / \mathrm{h}$, the track system was also changed. On the section about the first 6 kilometers, it was proposed to build 1 track and dynamic junctions (i.e. the second track between the passing stations) on the total length of almost 40 kilometers. However, in this case, too, the desired maximum speed has not been achieved anywhere (see Table 2.).

In variant 3 , in addition to increasing the speed to $160 \mathrm{~km} / \mathrm{h}$, the track system was also changed. As in the previous scenario, on the six-kilometer section, it was proposed to build 1 track, two on the section of almost 4 kilometers, one on the over forty-kilometer stretch and a dynamic one on the section of 15 kilometers. In this variant, the maximum speed has also not been achieved anywhere (see Table 2).

In option 4, in addition to increasing the speed to $200 \mathrm{~km} / \mathrm{h}$, the track system was also changed. As in the previous variants, on the six-kilometer section, it was proposed to build 1 track, two on a twelve-kilometer stretch and one on a more than forty-kilometer stretch and a dynamic passage on a stretch of 15 kilometers. In this variant, the maximum speed has also not been achieved anywhere (see Table 2 ).

\section{Analysis of the results}

As mentioned above, the desired maximum speed has not been achieved on the entire length of the section in question. The specification of the length of individual sections and the maximum speed achieved on them, broken down by variants, is presented in the table below. 
Tab. 2. List of maximum speeds for individual variants

\begin{tabular}{|c|c|c|c|c|c|c|c|}
\hline \multicolumn{2}{|c|}{ W1 } & \multicolumn{2}{|c|}{ W2 } & \multicolumn{2}{|c|}{ W3 } & \multicolumn{2}{|c|}{ W4 } \\
\hline $\begin{array}{l}\text { section } \\
{[\mathrm{km}]}\end{array}$ & $\begin{array}{c}\text { maximum } \\
\text { speed } \\
{[\mathrm{km} / \mathrm{h}]}\end{array}$ & $\begin{array}{l}\text { section } \\
{[\mathrm{km}]}\end{array}$ & $\begin{array}{c}\text { maximum } \\
\text { speed } \\
{[\mathrm{km} / \mathrm{h}]}\end{array}$ & $\begin{array}{l}\text { section } \\
{[\mathrm{km}]}\end{array}$ & $\begin{array}{c}\text { maximum } \\
\text { speed } \\
{[\mathrm{km} / \mathrm{h}]}\end{array}$ & $\begin{array}{l}\text { section } \\
{[\mathrm{km}]}\end{array}$ & $\begin{array}{c}\text { maximum } \\
\text { speed } \\
{[\mathrm{km} / \mathrm{h}]}\end{array}$ \\
\hline 0.340 & 100 & 3.488 & 160 & 3.500 & 160 & 3.500 & 160 \\
\hline 2.930 & 140 & 5.843 & 150 & 0.330 & 150 & 0.330 & 150 \\
\hline 0.570 & 120 & 0.502 & 140 & 5.510 & 160 & 5.530 & 160 \\
\hline 5.600 & 140 & 11.495 & 160 & 0.510 & 140 & 0.510 & 140 \\
\hline 0.200 & 110 & 1.154 & 140 & 11.490 & 160 & 11.470 & 160 \\
\hline 11.690 & 140 & 39.779 & 160 & 1.100 & 140 & 1.100 & 140 \\
\hline 0.580 & 130 & 0.643 & 140 & 81.040 & 160 & 7.110 & 160 \\
\hline 30.640 & 140 & 1.138 & 150 & 0.450 & 130 & 20.880 & 200 \\
\hline 0.895 & 120 & 39.468 & 160 & 4.645 & 100 & 3.620 & 160 \\
\hline 8.845 & 140 & 0.453 & 130 & & & 45.680 & 200 \\
\hline 0.610 & 130 & 4.612 & 100 & & & 3.680 & 160 \\
\hline 40.62 & 140 & & & & & 0.460 & 130 \\
\hline 0.430 & 120 & & & & & 4.705 & 100 \\
\hline 0.410 & 90 & & & & & & \\
\hline 4.215 & 80 & & & & & & \\
\hline
\end{tabular}

Source: own elaboration based on data obtained after entering information into the RailSys program

On the basis of this table it can be seen that only on some sections we managed to achieve the maximum for a given variant speed, on the other it was smaller, it may be due to driving in the reverse direction, turnouts or too short intervals between successive outposts, so the train is not in able to accelerate to the desired speed.

For the comparison of variants, in addition to the timetable introduced, the same rolling stock of the same routes was simulated without stopping, using the mileage characteristic for a given rolling stock. The rolling stock used for comparative analyzes were electric multiple units - EN57 and ED74 as well as the SA138 railbus. 
Tab. 3. Comparison of options

\begin{tabular}{|c|c|c|c|c|c|}
\hline \multirow{2}{*}{$\begin{array}{l}\text { section } \\
{[\mathrm{km}]}\end{array}$} & \multirow{2}{*}{ stock } & V1 & $\mathbf{V 2}$ & $\mathbf{V 3}$ & V4 \\
\hline & & \multicolumn{4}{|c|}{ time of travel [ h:min:s] } \\
\hline \multirow[t]{3}{*}{5,68} & EN57 & $0: 03: 15$ & $0: 03: 12$ & $0: 03: 12$ & $0: 03: 12$ \\
\hline & ED74 & $0: 02: 34$ & $0: 02: 24$ & $0: 02: 23$ & $0: 02: 25$ \\
\hline & SA138 & $0: 03: 22$ & $0: 03: 19$ & $0: 03: 19$ & $0: 03: 19$ \\
\hline \multirow[t]{3}{*}{3,69} & EN57 & $0: 02: 01$ & $0: 01: 55$ & $0: 01: 54$ & $0: 01: 54$ \\
\hline & ED74 & $0: 01: 36$ & $0: 01: 24$ & $0: 01: 25$ & $0: 01: 25$ \\
\hline & SA138 & $0: 02: 05$ & $0: 01: 58$ & $0: 01: 59$ & $0: 01: 59$ \\
\hline \multirow[t]{3}{*}{8,46} & EN57 & $0: 05: 12$ & $0: 05: 39$ & $0: 05: 11$ & $0: 05: 11$ \\
\hline & ED74 & 0:04:02 & $0: 04: 14$ & $0: 04: 13$ & $0: 03: 47$ \\
\hline & SA138 & -------------- & -------------- & -------------- & ------------ \\
\hline \multirow[t]{3}{*}{35,75} & EN57 & $0: 20: 42$ & $0: 20: 51$ & $0: 20: 41$ & $0: 20: 41$ \\
\hline & ED74 & $0: 16: 02$ & $0: 15: 07$ & $0: 15: 03$ & $0: 15: 12$ \\
\hline & SA138 & -------------- & -------------- & -------------- & -------------- \\
\hline \multirow[t]{3}{*}{51,43} & EN57 & $0: 30: 15$ & $0: 30: 15$ & 0:30:09 & 0:30:09 \\
\hline & ED74 & $0: 23: 12$ & $0: 21: 47$ & $0: 21: 25$ & $0: 21: 40$ \\
\hline & SA138 & ------------- & ------------- & ------------- & ---------- \\
\hline
\end{tabular}

Source: own study based on the timetable introduced into the RailSys program

As you can see, not always increasing the speed allowed on the line shortens the travel time. This is due to the fact that in a specific case the route leading by the added track may turn out to be slightly longer. In the case of the study of a single journey time, this may indeed result in a slight increase in travel time, however, when passing several trains it will be easier to pass, especially those from opposite directions because everyone will have their own track and prevent collisions.

It is impossible to draw a specific value from the program about the capacity of the line, therefore to illustrate the impact of the changes introduced in the next variants on the capacity of the lines, as many as possible EN57 trains passing through the entire route without stopping both from one side and the other. The capacity stocks were filled with the largest possible number of trains on sections A and B (in both directions). This has been tested for one hour (10:00 - 11:00). The results obtained are presented in the table below. 
Tab. 4. Comparison of hourly capacity in individual variants

\begin{tabular}{|c|c|c|c|c|c|}
\hline \multicolumn{2}{|c|}{ Variant } & V1 & V2 & V3 & V4 \\
\hline $\begin{array}{c}\text { number of train } \\
\text { pairs /h }\end{array}$ & whole section & 2 & 3 & 4 & 4 \\
\cline { 2 - 6 } & section A & - & - & 1 & 1 \\
\cline { 2 - 6 } & section B & 6 & 8 & 2 & 7 \\
\hline
\end{tabular}

Source: own study based on simulations made in the RailSys program

As you can see, the greatest capacity is provided by the changes proposed in option 4 . This shows that the problematic section is over an eight-kilometer section of the single-track line because the addition of an additional track in relation to W3 in W4 significantly increased the capacity. What's more, it showed the necessity of building a long passage at the monorail section from the end of section A. This clearly demonstrates that the key factor in increasing the capacity of the line is not increasing speed, and adding tracks, especially on long sections where trains cannot pass.

\section{Summary}

There are many factors that influence the capacity of a line. It is important to analyze the greatest possible number and their mutual influence on each other. Such analyzes carried out using modern tools available on the market, such as microsimulation programs, will facilitate the selection of the most favorable, also from an economic point of view, solution and adjustment to the market needs.

\section{Source materials}

[1] Abril M., Barber F., Ingolotti L., Salido M.A., Tormos P., Lova A.: An Assessment of Railway Capacity, Valencia, Spain.

[2] Bałuch M.: Podstawy Dróg Kolejowych. Wydawnictwo PR, Radom 2001.

[3] Basiewicz T.: Projektowanie linii kolejowych. Kraków 1982.

[4] Białoń A., Gradowski P., Gryglas M.: Wpływ nowoczesnych urządzeń SRK na wzrost przepustowości linii kolejowej, Logistyka, styczeń 2013.

[5] Cieślakowski S. Dr inż.: Materiały pomocnicze z przedmiotu Drogi i Stacje Kolejowe.

[6] Dąbrowa - Bajon M.: Podstawy Sterowania Ruchem Kolejowym. Funkcje, wymagania, zarys techniki. Oficyna Wydawnicza Politechniki Warszawskiej, Warszawa 2007.

[7] http:// www.plk-inwestycje.pl.

[8] http://taktici.cz/pl/mikrosimulace/.

[9] http://vision-traffic.ptvgroup.com/en-us/products/ptv-visum/functions.

[10] http://www.ertms.com/.

[11] http://www.rmcon.de.

[12] Institute of Transport, Railway Construction and Operation (IVE), University of Hanover, Germany. Handling of railway operation problems with RailSys.

[13] Instrukcja Id 12 (D-29). Wykaz linii. Polskie Linie Kolejowe, Warszawa 2009.

[14] Instrukcja Id-1 (D-1). Warunki techniczne utrzymania nawierzchni na liniach kolejowych, Warszawa 2005.

[15] Instrukcja Ie-4 (WTB-E10). Wytyczne techniczne budowy urządzeń sterowania ruchem kolejowym. Polskie Linie Kolejowe, Warszawa 2014. 
[16] Instrukcja Ir-1 (R-1) o prowadzeniu ruchu pociągów. Polskie Linie Kolejowe, Warszawa 2008.

[17] Instrukcja Ir-1a o prowadzeniu ruchu pociągów $\mathrm{z}$ wykorzystaniem sytemu ERTMS/ETCS poziomu 1. Polskie Linie Kolejowe, Warszawa 2014.

[18] Leksykon Terminów Kolejowych. Instytut Kolejnictwa., Warszawa 2014.

[19] Network Rail, RMCon, RailSys Standards Release 3.0, czerwiec 2014.

[20] Oleksiewicz W., Żurawski S., Zakład Inżynierii Komunikacyjnej Wydział Inżynierii Lądowej Politechnika Warszawska: Drogi Szynowe, Warszawa 2006.

[21] Opracowania Transportowe dla Województwa Pomorskiego, Część I Analiza potrzeb transportowych mieszkańców województwa pomorskiego, w celu wskazania niezbędnych do realizacji inwestycji kolejowych w perspektywie finansowania 2014 2020 wraz z częścią badawczą - Etap 1, Część B: Badawcza, Załącznik 3 Badania popytu na usługi przewozowe, Gdańsk, grudzień $2013 \mathrm{r}$.

[22] PKP Polskie Linie Kolejowe S.A.: Lista kryteriów do analizy wielokryterialnej wariantów inwestycyjnych, Warszawa 2014.

[23] Prezentacja: Andrzej Torun, Instytut Kolejnictwa: Wptyw systemu sterowania realizującego zasadę ruchomego odstępu blokowego na przepustowość linii kolejowej, czerwiec 2013.

[24] Prezentacja: Hal Bransby, Rupert Dyer: Rail Operations and RailSys Training, lipiec 2013.

[25] RailSys User Manual 8.9. RMCon, Hanover, marzec 2013.

[26] Regulaminu przydzielania tras pociągów i korzystania z przydzielonych tras pociągów przez licencjonowanych przewoźników kolejowych w ramach rozkładu jazdy pociągów $2013 / 2014$.

[27] Rogowska M.: Wykorzystanie programu mikrosymulacyjnego do badania przepustowości linii kolejowej na przykładzie odcinka linii. Praca dyplomowa magisterska, Wydział Transportu Politechniki Warszawskiej, Warszawa 2015.

[28] Rudzianiec M.: Przepustowość linii kolejowych w obrębie aglomeracji - układy stacyjne, transport.info, grudzień 2014.

[29] Towpik K.: Infrastruktura transportu kolejowego. Oficyna Wydawnicza Politechniki Warszawskiej, Warszawa 2004.

[30] Wawrzyniak A.: Urządzenia sterowania ruchem kolejowym na liniach dużych prędkości, Wiedza Techniczna, nr 2/2010.

[31] wikipedia.org.pl.

[32] www.opentrack.ch.

[33] Związek Niezależnych Przewoźników Kolejowych: Wąskie gardła na polskiej sieci kolejowej [raport z badań], Warszawa, maj 2012. 